\title{
Multilevel Design in the Implementation of Blended Learning in Nonformal Education Unit
}

\author{
${ }^{1}$ Indonesia University of Education, Indonesia \\ ${ }^{2}$ Singaperbangsa Karawang University, Indonesia \\ ${ }^{3}$ Siliwangi University, Indonesia \\ ${ }^{4}$ Tohoku University, Japan \\ *Email: yanti.shantini@upi.edu
}

Yanti Shantini $^{1 *}$, Dayat Hidayat ${ }^{2}$, Lesi Oktiwanti ${ }^{3}$, Takahashi Mitsuru ${ }^{4}$

Submitted: 4 December 2020. Revised: 13 January 2021. Accepted: 13 February 2021

\begin{abstract}
CLC as one of the non-formal educational institutions affected by the COVID 19 outbreak must organize online teaching and learning activities under government instructions as an effort to prevent transmission of the COVID 19 pandemic. Lack of experience in conducting online learning makes institutions confused about running the learning process due to educators and managers' limited ability to implement online education. It is necessary to study more deeply what learning strategies CLCs should carry out during the pandemic period. The approach used in this study was a mixed-method with 10 CLC respondents spread across West Java. From the findings in the field, learning at CLC during the pandemic was still ongoing. Tutor only used message applications for delivering learning material and evaluation process. They do not even implement it in the online learning management system. For this reason, CLC can pilot a multilevel blended learning system model. The implementation of the model system starts from institutional management, program management, to learning management by tutors.
\end{abstract}

Key words: Blended learning; Nonformal Education, Nonformal Education Unit

How to Cite: Shantini, Y., Hidayat, D., Oktiwanti, L., \& Mitsuru, T. (2021). Multilevel Design in the Implementation of Blended Learning in Nonformal Education Unit. Journal of Nonformal Education, 7(1), 55-64.

DOI: http://dx.doi.org/10.15294/jne.v7i1.27544

\section{INTRODUCTION}

COVID 19 pandemic that has occurred since 2019 and has started to spread in Indonesia early March 2020 (Satgas COVID, 2020) has given significant impacts on society's life in many sectors. Education is one of them. The system is done online during this situation, aligned with the circular letter from the government as one of the efforts to prevent and handle the transmission of COVID 19 (Surat Edaran Nomor 2 Tahun 2020 Tentang Pencegahan Dan Penanganan COVID 19, 2020). In line with it, The Ministry of Education and Culture Republic of Indonesia reveals that the total number of students getting affected by COVID 19 from Early Childhood Education, Basic Education, to Middle Education is 68 million students (cnnindonesia, 2020). It highly influences the process and result of students learning during COVID 19 Pandemic period. Schools that have been ready to make use of technology in their learning will surely not find any obstacles and serious problems, different from those that have not optimally made use of technology that surely gets problems due to this (Abidah et al., 2020). Similar condition has also taken place in the context of nonformal education unit such as Nonformal Early Childhood Education, CLC, Training Institution, and other similar Education units.
Nonformal Education Unit as a place for society to carry out education has also been affected by COVID 19 Pandemic. It is difficult to obtain data of learners getting affected by COVID 19 in Indonesia. Despite this, there have been several studies conducted in order to measure the use of information and technology in the context of Nonformal Education Unit. Technology is utilized by CLC as one solution to overcome the great distance between community living places and Learning Center, providing learners with electronic-formed materials or online materials and online learning as well. (Sutisna et al., 2020). Other studies explain that some CLCs and Courses have applied educational technology in the creation, use, management, and evaluation to serve learners; however, they still need assistance to optimally use their abilities in the classification and selection of right educational technologies, aligned with the needs, with effectiveness, and with efficiency (Hanum, 2019). Further, apart from structures, infrastructures, and learners, aspects on human resources, in this case, organizers and tutors also need improvement, especially in literacy of information and technology realized through many activities, such as trainings, technical guidance, and workshops (Sunarwan, 2017). Those studies have indicated the need of management improvement in the application and utilization of technology in Nonformal Education Unit. Discussions on technology-based learning man- 
agement are still rare to hold, thorough applications of technology in nonformal education units are still difficult to put into actual, requiring gradually transitional period achieved through one alternative method, blended learning that combines face-to-face/ direct and online learning. Blended learning combines the best aspects of online learning, structured face-toface activities, and actual world practice. The more advanced information technology is, the higher the need of blended learning becomes (Senpai, n.d.). Blended learning is beneficial to create more meaningful learning both for individuals and socials (Yulia, 2017). Therefore, blended learning is considered a right choice because it combines online theories and direct practices.

Blended learning integrates the benefits of collaborative, independent, and problem-solving based learning to achieve broad-type learning involving the creation of physical and virtual environment and other types of media (Hawi \& Sudira, 2019). Many different studies on blended learning have shown that blended learning approach that has been developed has gained positive feedbacks in terms of its development and implementation (Dwiyogo, 2018). Considering its suitable characteristics, blended learning can be implemented in Indonesia Nonformal Education Unit. Therefore, this research aims to describe possible design of conceptual model of implementation pattern of blended learning in learning activities within nonformal education unit. This is done by firstly study the prior condition of Indonesia Nonformal Education Unit in the implementation learning service during pandemic period. This study is carried out as one effort to form society as lifelong learners by balancing the use of technology and socialization competence offline or in the real life.

\section{METHODS}

This study employed mixed method, combining elements of qualitative and quantitative approaches for large goals and thorough understanding and evidence (Almalki et al., 2016). The model used in this research was mixed method model of Sequential Explanatory Design, featured by the collection of data and analysis of quantitative data on the first stage, continued with the collection of data and analysis of quantitative data on the second stage (Creswell, 2009). In the first stage, the data collection were carried out by distributing questionnaire in order to find out prior condition of the use of technology in nonformal education unit, followed by observation during the training process, seeking probability of implementation pattern that could be applied by tutors in each unit. After the data were analyzed, literature or document study related to the implementation of blended learning in the unit of education was carried out.

The study involved 10 units of CLCs in West Java Province, consisting of; 1 CLC in Bandung City, 1 CLC in Cimahi, 1 CLC in Bandung Regency, 3 CLCs in Tasikmalaya City/ Regency Areas, 4 CLCs in Karawang Regency, and 50 tutors and organizers who participated in Blended Learning training.

\section{RESULTS AND DISCUSSION}

\section{Education Service in Indonesia Nonformal Educa- tion Unit during Pandemic}

The collection of prior data was done by distributing questionnaire online in order to gain information on condition of nonformal education unit in facing COVID 19 pandemic and to see the extent of technology utilization in the learning process.

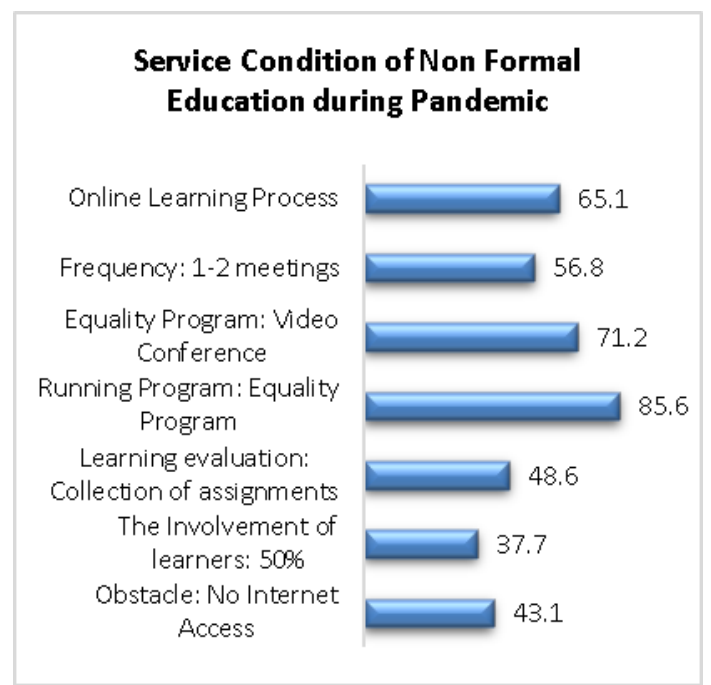

Figure 1. Condition of Program during COVID 19 Pandemic

Figure 1 illustrates the condition of service of nonformal education unit during pandemic period. It shows that during this period, $65.1 \%$ of institutions conduct online learning process. $56.8 \%$ of institutions have 1-2 meeting frequencies to conduct online learning process. $85.6 \%$ of equivalency programs are done offline, while $71.2 \%$ of equivalency programs are carried out online. Further, $48.6 \%$ of institutions implement learning evaluation by checking the completeness of task submitted by learners. Even so, only $50 \%$ of learners within $37.7 \%$ of institutions are actively involved in this task submission, while 50\% others are conversely. It occurs because learners face obstacles. The main obstacle faced by $43.1 \%$ of institutions is that learners do not have credit for internet quota. 


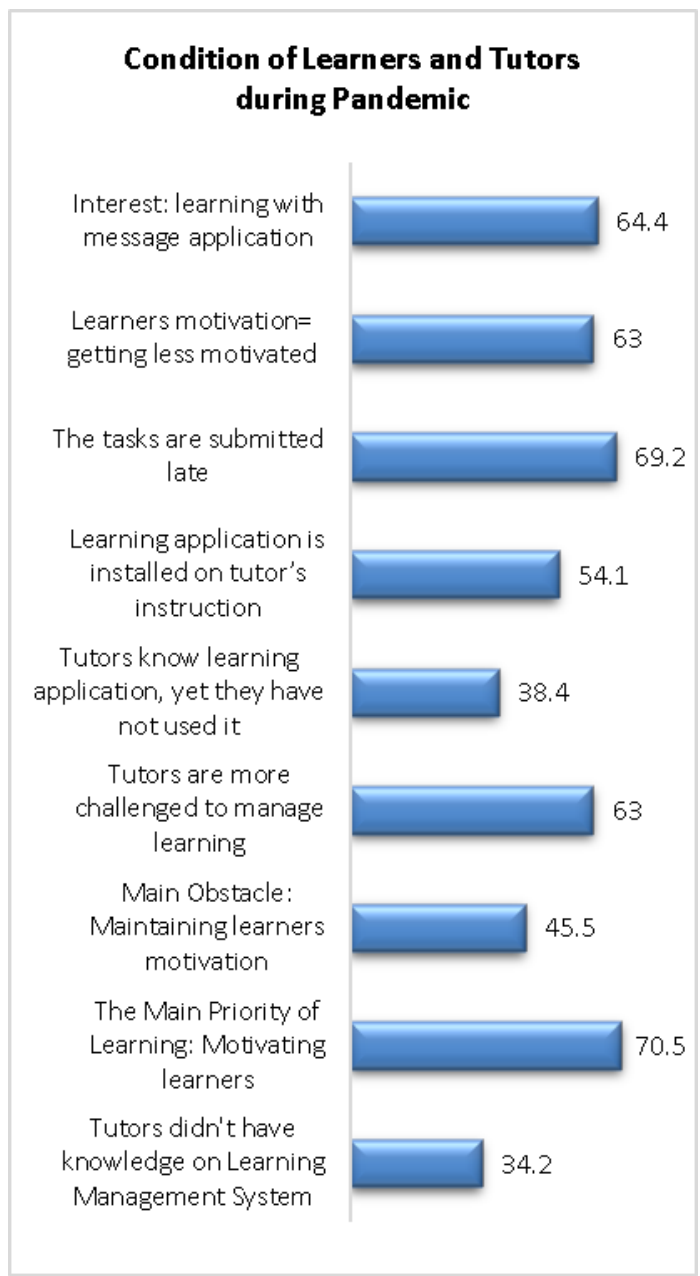

Figure 2. Conditions of Learners and Tutors during Pandemic

Figure 2 explains the conditions of learners and tutors during pandemic period. The data describes that $64.4 \%$ of institutions make use of message applications, such as whatsapps, line, etc., in their learning process. Message applications as one of the media to connect the message are expected to become one of the solutions to overcome communication failure between tutors and learners, to accommodate different learning style, interest, intelligence, and great distance of living places (Putu \& Yuliartni, 2019). Furthre, during pandemic period, learners experience demotivation, as shown in the chart that $63 \%$ of institutions undergo this case, giving impact on the late task submission of learners, which is done by $69.2 \%$ of learners. Furthermore, institutions making use of learning applications reveal that learners based on instructor's instructions, not self-initiative, install $54.1 \%$ of learning applications. This is due to the little number $(38.4 \%)$ of tutors have knowledge on the learning applications, despite its non-optimal use. The chart also indicates that COVID 19 pandemic motivates $63 \%$ of tutors to digitally manage the learning. Apart from that, $34.2 \%$ of tutors acknowledge that they have no knowledge regarding learning man- agement system. $70 \%$ of tutors have not yet made use of the technology, focusing more on giving motivation to learners to keep participating in the learning process because $45.5 \%$ of them feel that the main obstacle is to keep learners' motivation and has no relation with technology.

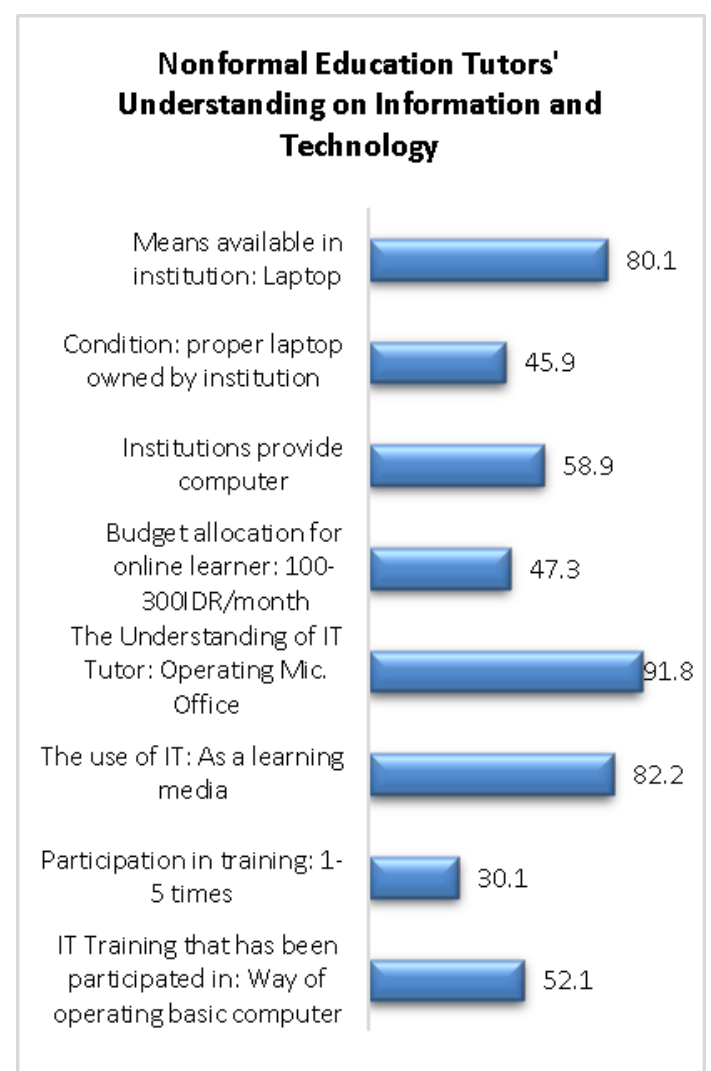

Figure 3. Nonformal Education Tutors' Understanding on IT

Nonformal Education tutors' understanding on information and technology was viewed from the availability of the structure and their abilities to make use of technology. In relation to this, Figure 3 shows that $80.1 \%$ of institutions provide IT in the form of laptop, with $45.9 \%$ of them have proper laptop, and $58.9 \%$ of institutions provide computer for their learners. Further, the graph explains that $47.3 \%$ of institutions allocate 100-300 IDR/month for online learning process. $91.8 \%$ of tutors' abilities are still in basic level to make use of IT, including in operating computer/laptop such as Microsoft Office program. Therefore, only $82.2 \%$ of new information and technology as learning media can be utilized resulted in the nonoptimal use of technology. Further, the chart also demonstrates that only $30.1 \%$ of tutors participate in the training related to the utilization of technology, attending 1-5 trainings. $52.1 \%$ of tutors participate in computer basic operation trainings. Three factors influencing the understanding of Indonesia Nonformal Education tutors on IT, viewed so far from the data, included the participation in the trainings, the 
availability of structure and infrastructure of IT, and the habituation of learning results. In line with it, there are some keys influencing effective online learning, namely: condition where online learning is used, application from the online learning itself, and the individual using the application (Murad et al., 2019). To successfully conduct online learning, the implementer needs to pay attention to its influencing factors, and thus, special attention is required in its preparation. The use of Computer Information and Technology-based media in the learning process in CLC, in general, is not optimally used, due to the limited structure of computer apparatus and thus the use of the media by tutors can still be considered weak (Sutisna, 2016).

\section{Conceptual model of Multilevel Design in the Im- plementation of Blended Learning in Indonesia Nonformal Education Unit}

Condition of nonformal education institution during pandemic period becomes one description of the institution's readiness in making use of the technology in the process of its management and is learning. The impact of online learning in the ongoing pandemic situation shows that online learning is legible, cheap (Agarwal \& Kaushik, 2020) that should be parts of learning process in Nonformal Education Institutions. Learners already have basic facilities required for participating in online learning, online learning has flexibilities in its implementation, is able to encourage independent learning, and motivates learners to be more active in the learning (Sadikin \& Hamidah, 2020). Therefore, efforts are needed to apply the model easily by Nonformal Education Institutions. Many studies show that blended learning model has been proven to be effective to improve learners' learning independence in CLC, blended learning as a combination of traditional and online classes have strong points and does not ignore the meaning of face-to-face contact (Sutisna, 2016). Blended learning approach gives positive impact on teaching and learning process. This method is better applied as complement to the conventional learning (Sanjaya, 2013). The application of blended learning in the learning process varies, aligned with the learning field, learners characteristics, and learning results; it must be learner-centered learning design, must be able to adapt with the technology used, with the time, with the instructional learning, and with the effectiveness in the improvement of learners' skill (Dewi et al., 2018). Parts of online learning give more time for learners to think thoroughly of their responses so that they can better express their thought. This aspect facilitates introvert learners' needs and those who are not comfortable to express their view in front of other people. Learners feel more that they have qualified time to think over ad respond to asynchronous discussion more effectively (Firdaus et al., 2020). Many scientists and practitioners believe that by combining conventional and e-learning, learning process will be more interesting, accessible and effective for adult learners (Zainuddin \& Keumala, 2018). Therefore, offline ad online learning combinations are a just collaboration if it is well implemented and professionally managed. Apart from that, after applying blended learning, learners are able to develop critical thinking so that they can give simple explanation, build basic skill, give further explanation, decide on action to solve problems, and can withdraw conclusion correctly (Lukitasari et al., 2019). Three main factors influencing effectiveness of e-learning and blended learning include characteristics of instructor/ tutor, technology, and characteristics of learners. These factors show the need to test characteristics of learners in the use of effective learning technology and show that characteristics of users give impact on the intention of behavior to use the technology (Kintu et al., 2017). In line with it, dimensions of blended learning consist of several aspects, as follows: space (face-to-face, online, autonomy) and time (synchronous) for teachers and students and contents' interaction, pedagogy (conventional, converse) and locus control (teachers, students, groups), Media to achieve knowledge (expository, active, interactive media), learning experience (formal, nonformal, informal), learning environment (private/ network, in the workplace/at home, virtual class/ physical class (Galvis, 2018). Therefore, blended learning class needs preparation in its implementation. Despite its main preparation, in relevance with teaching staff development, there are also other factors in need of analyses so that a just decision can be withdrawn. Those factors, among others are; (a) growing bigger community among Institutions of Nonformal Education, (b) preparing more effective online teaching, (c) acknowledging and appreciating staff teaching online, and (d) giving institutional supports actively and acknowledgment through worthwhile budget, training, support for disciplinary research, and publication for online environment (Lim \& Ripley, 2007). Despite this, the role of tutors is also important. Tutor must manage the combination carefully between activities and projects that will grow motivation, while at the same time, giving access for learners regarding information and knowledge that in the beginning motivate them to participate in the program (Fisher et al., 2013). Tutor must explain expectations, start, and guide online discussion and explain the evaluation criteria since the commencement of learning (Youngblood et al., 2001). Below is the model of blended learning that can be used as reference to be applied in nonformal institutions applying the model. 


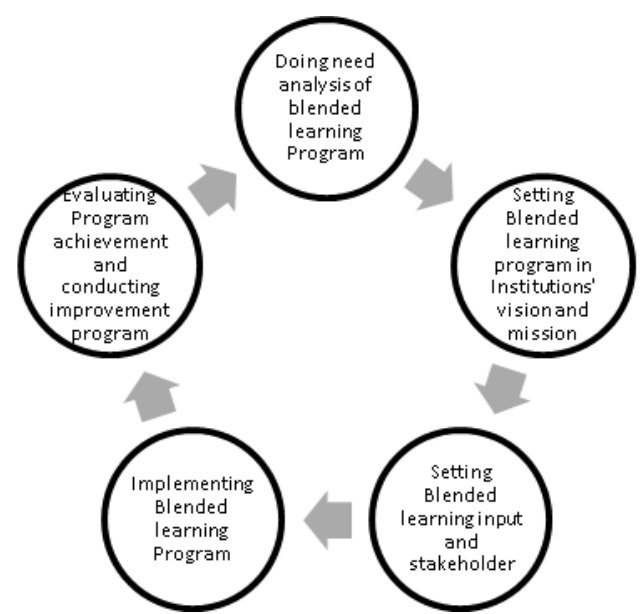

Figure 4. Steps of Implementation of Blended Learning in Nonformal Education Unit

Procedures taken to implement blended learning model are divided into three stages, covering: (1) planning, (2) implementation, and (3) evaluation (Sutisna, 2016). The figure above illustrates steps of blended learning application in Nonformal Education unit. The step commences with first, doing needs analysis of blended learning program, in Indonesia Nonformal Education program, whose program services are institutionally structured such as CLC and Training Institutions. In this case, organizers need to firstly set the need and potential owned by the institutions. The potential, in this case, refers to whether the institution has required resources to implement long distance learning by using blended learning as one approach of learning. Resources in this context refers to human resources, namely organizers and tutors who understand the development of materials by using blended learning, henceforth, tutors must be able to facilitate online learning because learners characteristics are limited by space and time (Arriany $\&$ Laksono, 2020). The second resources are structures and infrastructures that support the implementation of learning by using blended learning approach, such as adequate computer, internet connection network, and the completeness of other learning media that can be used by tutors in the design of learning materials used in blended learning way. Needs, in this case, refers to society's needs in learning participation since it is impossible to participate in conventional/ face-to-face/ direct learning. This condition relates to limited time and place of participants, making them impossible to attend to the learning place. Therefore, there is a need to firstly research and map whether society indeed needs the learning service by using this approach.

The second step is setting long distance learning activities as parts of vision and missions of institutions. Institutions need to set their vision and missions in written to provide learning service that facili- tates learners or societies in general to participate in long distance learning. The setting of vision and missions is important to conduct because both will give directions in the development of program service in the institution. Organizers and tutors create long distance learning as parts of service development for all learners, and become innovations offered to societies in general. The third step is setting blended learning input and stakeholder. In this step, institutions need to set components involved in long distance learning activity as a condition that needs to set up and fulfilled in effort to conduct long distance learning, as an offer of learning activity in the institution. The input, in this case, refers to all things relevant with learning activity, including learners, learning program (curriculum), learning process, educators (tutors, facilitators, resource persons), and learning structure and infrastructure. The stakeholder, in this case, defines all parties that contribute directly to long distance learning activity, by acknowledging the results of learning or those who assist in the facilitation of long distance learning. Stakeholder, in this case, refers to department of education that has directly given guidance such as inspector, while those who acknowledge the result of learning are partners of institutions such as companies that later will accept graduates to be employed.

The fourth step is implementing blended learning. Blended learning activity offered by the institution is carried out by using many different kinds of approaches; asynchronous e training (place and time between the instructor and the participants are different) and synchronous e-training (different place, but same time). To gain more complete information regarding this, learners can learn when blended learning is implemented on the program level. The benefit of the approach can be put into actual only if many opportunities of involvements given by the two contexts are developed to stimulate learners with different kinds of experiences, to train learners to learn individually and collaboratively (Jeffrey et al., 2014). The fifth step is evaluating program and making improvement. Similar to conventional learning, long distance learning also needs evaluation in terms of its achievement and using the data to keep making improvement. Tutors conduct analyses on learners' characteristics. This is done by mapping out the characteristics of learners viewed from aspects of abilities in online learning participation. These aspects include; a) the ability in science and technology mastery, b) the possession of technology apparatus/ tools, c) the availability of internet network, and d) the ability to provide credit of internet data.

Apart from those steps, nonformal education unit needs to pay attention to steps done in the learning 
program, as follows: first, setting learning objectives to attain.

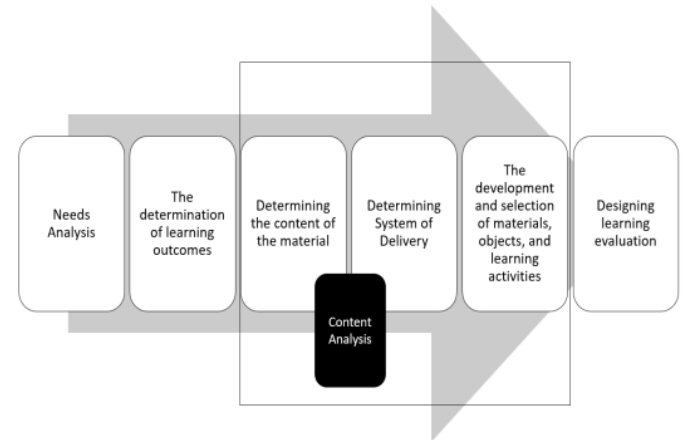

Figure 5. Flow of Blended Learning Materials

Learning materials in blended learning is an important thing. The Figure 5 shows the flow of blended learning materials, which is started with doing needs analysis, setting learning outcomes, deciding on the content of the materials, determining system of delivery/ teaching, of development and of choice of learning evaluation. Efforts to determine content to give in blended learning are known as content analysis, this step is a part of the process of materials determination and delivery system determination. Content analysis is done to give right, effective, and optimal materials used by learners.

Second, doing content analysis by tutors

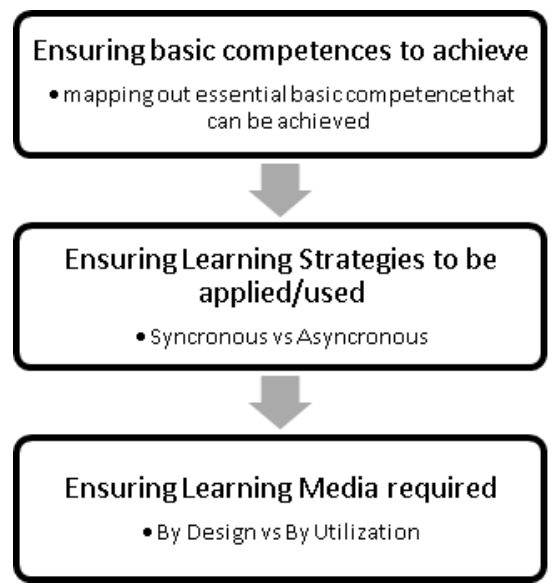

Figure 6. Flow of Content Analysis

To produce an effective explanation for learners, Content analysis is done through the following flows: a) Ensuring Basic Competences to be achieved: this process is done by mapping out basic competences that are the most significant/ essential that can be achieved by learners through blended learning process, b) Ensuring learning strategy used in the process: this is done by having strategy synchronous or asynchronous aligned with the material and competences to achieve and is done optimally, c) Ensuring learning media needed for the learners in the program: this process is done by deciding precise learning design that is aligned with the needs, whether this is based on design or based on the utilization of tools. In this process, content of idea or concept that must be delivered must support the practice that encourage the discipline of the content by formulating a more precise definition (Dziuban et al., 2018). An effective teaching requires accurate content knowledge and conceptual understanding added with an interesting presentation. Therefore, instructional designer must have a conceptual framework (Arghode et al., 2017). Content in a well-structured domain (or close) consists of concept that is decided strictly and unstructuredly, characterized by problems with many solutions and many kinds of alternatives, such as social science, management science, discipline of environment and discipline of design that needs reflective practice (Buzzetto-More, 2007). It needs well attention and consideration from tutors.

The sending of information online is more doable in a real time, with the voice and video, followed by many kinds of sources or frames available at the same time to perform. Therefore, sharing information and transferring knowledge at present take place in data environment which is rich and multiple, similar to news room or war situation that offer unlimited practical access (Buchen, 2012). Therefore, blended learning is applied by using many types of media, applied in an ideal way to solve the problem (Isti'anah, 2017). There are three grounds of using learning media that can be used as consideration for tutors in choosing accurate media in line with the contents and aims of learning (Musfiqon, 2012: 28). Those grounds include: (1) Philosophical Ground, that is the use of media must be based on truth value that has been discovered and agreed by many people, (2) Psychological Ground, that is the use of learning media of a tutor also needs to pay attention to psychological situation of learners who develop variously, and (3) Sociological Ground, that is in the use of media, a teacher needs to consider social background of the learners in the school. If the media used do not suit the social background of the learners, the learning materials delivered to the learners cannot be optimally accepted (Musfiqon, 2012). In this case, therefore, the content and media must be able to get well integrated so that blended learning can run effectively. There are several kinds of learning materials, among others: (1) Fact, that is all things that are in the forms of fact and truth, (2) Concept, that is all that in the forms of understanding - new understanding that can emerge as a result of thought, (3) Principle, that is in the forms of things - the main thing, the core, and has the most important position, (4) Procedure constitutes steps - systematic or sequential steps in doing activities and explaining chronology of system, and (5) Attitude or value constitutes a result of learning aspect of attitude, for example honest value, care, 
helping each other, spirit, and interest in learning and working, and so on (Isdisusilo, 2012: 150).

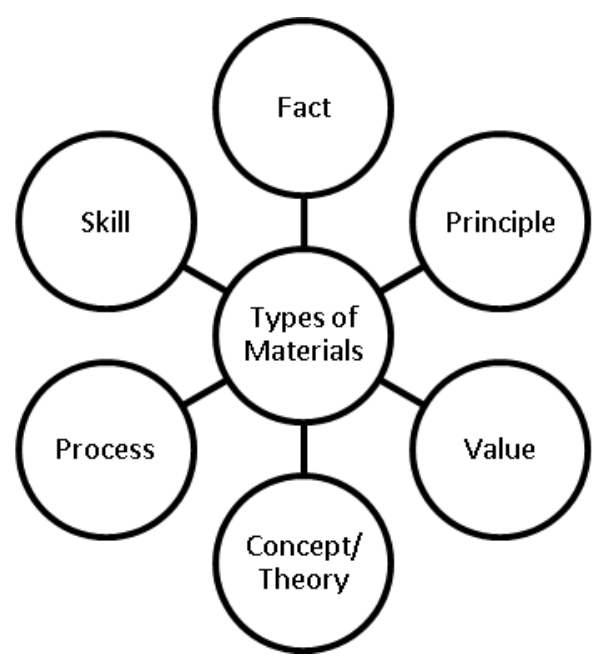

Figure 7. Types of Learning Materials

Table 1. Types of Material Selection for Online Learning

\begin{tabular}{clcc}
\hline Num. & Types of Materials & Online Learning \\
\hline 1 & Fact & $\sqrt{ }$ & \\
2 & Principle & $\sqrt{ }$ & \\
3 & Value & $\sqrt{ }$ & \\
4 & Concept/ Theory & $\sqrt{ }$ & \\
5 & Process & $\sqrt{ }$ & X \\
6 & Skills & $\sqrt{ }$ & X \\
\hline
\end{tabular}

The Figure and Table above show types of materials that can be delivered in blended learning. These types of materials can be delivered offline and online, aligned with the needs and conditions, those are types of materials in the forms of process or skills. Therefore, blended learning does not necessitate learning through online method but also combined with faceto-face learning and thus it needs right materials for the purpose (Dissriany \& Banggur, 2018).

Third, choosing types of blended learning to implement. There are several kinds of blended learning, among others are: a) Station Rotation Blended learning, learners take turn through station on permanent schedule, in which one of the stations is online learning. This model is the most used in general in elementary school because tutors get used to having rotation in center and station, b) Lab Rotation blended learning, learners rotate station on a permanent schedule enabling them to regulate flexible schedule with tutor to use existing computer lab, learners spend one part of their learning in the computer lab through online curriculum based on their own pace individually. Then, they participate in other learning in class with a tutor to strengthen what they have learnt in the lab, they have learnt basic things and develop their understanding on online learning. It is then continued with face-to-face learning to question things they have not yet understood or to improve the next learning, c) long distance blended learning (also known as Enriched Virtual). In this learning, the focus of learners is to complete online task while meeting the tutor sometimes/ based on the needs. This approach is different from Flipped Classroom model in terms of balanced online learning time and face-toface interaction. In this learning model, learners will not see/ work with/ learn from the teacher every day face-to-face, yet, in the 'reverse' management, d) Flexible blended learning, online learning becomes the backbone of learners' learning, even directing them to offline activities on certain time, schedule is adjusted individually in between learning modalities. Most of them learn within the unit, except for homework. Tutor gives flexible and adaptive face-to-face support in line with the needs through activities such as instructions of small group, of group projects, and of individual guidance, e) 'Flipped Classroom blended learning. It is possible that the most known blended learning, 'Flipped Classroom', is introduced with content at home, and it is practiced in the institution with the support from the tutor and/ or partner, f) Individual Rotation Blended learning. This model enables learners to play through station, yet, based on the schedule of individual that has been set up by the tutor or software algorithm. Unlike other types of rotation models, this type of rotation makes individuals take turn on the activities that have been set up in their play list, meaning that they do not have to rotate to every station, g) Project-Based blended learning. Online project-based learning, accessed either individually or in the form of course and instruction of face-to-face and collaboration to design, repeat, and publish project-based tasks, products, and relevant artefact, h) Self-Directed Blended learning. Learners use combinations of online learning and face-to-face to guide private investigation, to achieve goals of formal learning, to get connected with tutors physically and digitally, and so on. Since the learning is self-directed, role of 'online learning' and physical tutors changes, and there is no formal online course to be completed. In this learning, one challenge for tutors is that they can evaluate and (there is still question regarding it) the success of learning experience is achieved without canceling authentication. For learners, the challenge is to seek models of product, process, and potential that can give type of spark, able to maintain learning while at the same time enough being aware of finding out what succeed and why, as well as making adjustment. Learners will need support to guide themselves through autonomy and selfcritics, h) Inside-Out blended learning. In this learning, experience is planned to 'finish' or 'end' outside of physical classroom, but still needing and gaining 
advantages from the strong points of physical and digital rooms. Both in Outside-In and Inside-Out models, the character of 'online learning' is less important and the focus is on platform, space, people, and opportunity outside of the school (Online component can be in the forms of independent question and/or courses and formal eLearning curriculum.). Because the pattern of learning is 'inside-out', Mixed Project-Based Learning is the best example of InsideOut learning model. Similar to mixed Inside-out learning, there is a need for learners to be guided from the experts, to learn feedback, content teaching, and psychology and moral supports from daily faceto-face interaction, i) Outside-In blended learning. In this learning, experience is planned to be 'started' in non-academic digital and physical environments used every day, yet it is finished inside the classroom. Score of traditional letter and scoring form, or teaching and learning that are less traditional using classroom only as 'platform' of safe place to share, to become creative, to collaborate, and to give and to receive feedback that can grow the work of the learners. While the pattern is Outside-In, unlike mixed long distance learning, learners still need guidance, teaching, and support from face-to-face interaction every day, j) Additional blended learning. In this model, learners finish either online task fully to complete daily face-to-face learning, or fully experience face-to-face learning to complete learning achieved in the course and in online activities. The big idea, in this context, is to complete the goal of critical learning within one space entirely, while the 'opposite' space can give learners specific complement experience that cannot give to or cannot be given by other learners, k) Mastery-Based blended learning. Learners take turn between online and face-to-face learning (activity, evaluation, project, and so on.) based on the completion of mastery-based learning goals. Evaluation design is very important in every mastery-based learning experience; the ability to use face-to-face and digital evaluation tool can be strong or "complicated' depending on the pattern of thinking of the learning designer. Even though the educator does not control the learning environment online, it is very important to understand way of delivery, learners' characteristics, and different environmental aspect to interact and influence learning in order to make it run effectively (Stone, 2018).

Fourth, tutors prepare the completeness of learning materials that are going to be used as blended learning materials (select media and material). After doing the mapping of types of materials and determining types of blended learning to use, the next step is to prepare the completeness of learning materials that are going to be delivered to learners. The preparation of the materials can be taken from many reliable learning resources. Fifth, develop learning materials by using mastered learning media (use in the virtual environment). The collections of learning materials that have been done are later prepared to be included in the form of learning media that will be used and has been mastered. The change of the form of learning materials into media is done so that the materials can be delivered virtually and so its appearance is more appealing. The functions of learning media in detail, among others, are: (1) Media as a Source of Learning, that is through media learners receive message and information to form new knowledge in the learners themselves, (2) Semantic Function, that is the ability of media in adding the vocabulary (verbal symbol) whose meaning can be really understood by learners, (3) Manipulative Function, that is the ability of media in showing back one object or event using many ways, in line with the conditions, situations, goals, and targets, (4) Fixative Function, that is function that deals with the ability of one media to catch, save, show back one object or event occurred long time ago, (5) Distributive Function, that is within once use of one material, object, or event, can be followed by learners in a big number (unlimited) and within a wide scope in order to improve efficiency of both time and cost, (6) Psychological Function, that is the media can arouse feeling, emotion, and level of reception or rejection of learners on something, resulting in the emergence of attitude and interest of learners on learning materials, and (7) Socio-Cultural Function, that is the ability of media to overcome socio-cultural obstacles among learning communication participants (Asyar, 2012).

Sixth, implementing blended learning. This process is done by implementing the learning process with the learners, delivering the materials, and carrying out the process in line with what that has been set up to attain learning goals and competences that have been designed previously. Seventh, conducting blended learning evaluation. This process is done by ensuring the whole processes of learning that have been planned and implemented aligned with the learning goals and by seeking the condition of achievement of learning competences through blended learning.

Based on this blended learning model design, it is clear that the implementation of the model in nonformal education unit needs a well-prepared design and preparation in terms of things that include in the elements that have been parts of the components of blended learning implementation. The effectiveness of blended learning implementation is influenced by some main factors, as follows: (1) there are proper structures and infrastructures, (2) tutors still need improvement with regard to computer and information and technology by reading and training both independently and formal training, and (3) learners 
need access to computer and internet, and they need to be able to make use of online learning (Dissriany \& Banggur, 2018). Contemporary literature analysis shows the possibility to describe process and procedure to develop online learning community as a model, containing series of events consisting of factors of presage, of process, and of product. Presage factor elaborates condition for the development of community, while community factor puts in detail strategies used by instructors to develop the feeling of community, product factor, on the other hand, particularizes the feeling of community experience, among other results (Brook \& Oliver, 2003). This case is aligned with several steps to be taken by nonformal education institutions in the implementation of blended learning in a professional way without leaving those factors. Online learning will keep being more important for adult learners. Challenge for educators is that how to provide positive "social" environment using electronic media. Technology will keep changing along with the development of new technology. Instructors need to adapt, change, and keep learning regarding how this "electronic" environment is used to grow social situation, and they need to recognize their roles as agents of changes (Cercone, 2008).

\section{CONCLUSION}

Identification of nonformal education institutions condition in the implementation of online learning can be seen clearly during the COVID 19 pandemic, the lack of preparation of institutions in facing the change of learning pattern from offline to online needs a more organized preparation. Therefore, the preparations of structures and infrastructures, human resources, and other supporting components are required to get more ready in doing this transition process. One effort to do in order to simplify the process is through a structured and systematic blended learning model.

Many studies show that blended learning has been able to give effective and efficient learning in the context of nonformal education institutions. The possibility to develop multi-level blended learning model that has been designed can be implemented in nonformal education institutions, taking into account some considerations to design and prepare well by each institution. Factors that influence the implementation, including structures-infrastructures, the ability of human resources, and the commitment of institutions need to be prepared well so that the implementation of blended learning can be done optimally.

\section{REFERENCES}

Abidah, A., Hidaayatullaah, H. N., Simamora, R. M., Fehabutar, D., \& Mutakinati, L. (2020). The Impact of Covid-19 to Indonesian Education and Its Relation to the Philosophy of "Merdeka Belajar." Studies in Philosophy of Science and Education, 1(1), 38-49.

Agarwal, S., \& Kaushik, J. S. (2020). Student' s Perception of Online Learning during COVID Pandemic. The Indian Journal of Pediatrics, 87(7), 554.

Almalki, S., Centre, E. L., Arabia, S., \& Centre, E. L. (2016). Integrating Quantitative and Qualitative Data in Mixed Methods Research - Challenges and Benefits. 5(3), 288-296.

Arghode, V., Brieger, E. W., \& McLean, G. N. (2017). Adult learning theories: implications for online instruction. European Journal of Training and Development, 41(7), 593-609.

Arriany, I., \& Laksono, A. D. (2020). Pelatihan ELearning Untuk Tutor Pendidikan. Journal Communnity Development, 1(2).

Asyar, R. (2012). Kreatif Mengembangkan Media Pembelajaran. Jakarta: Referensi Jakarta

Brook, C., \& Oliver, R. (2003). Online learning communities: Investigating a design framework. Australian Journal of Educational Technology, 19(2), 139-160.

Buchen, I. H. (2012). Customizing Online Learning. World Futures Review, 4(2), 179-181.

Buzzetto-More, N. . (2007). Advanced Principles of Effective e-Learning Edited by. In Informing Science Press.

Cercone, K. (2008). Characteristics of Adult Learners with Implications for Online Learning Design. Characteristics of Adult Learners with Implications for Online Learning Design, AACE Journal, 16(2), 137-159.

Creswell, J. W. (2009). Research Design: Qualitative, Quantitative, and Mixed Methods Approaches. SAGE Publications Inc.

Dewi, K. C., Ciptayani, P. I., Surjono, H. D., \& Priyanto. (2018). Study of Instructional Model on Blended Learning in Polytechnic. Cakrawala Pendidikan, XXXVII(2), 270-281.

Dissriany, M., \& Banggur, V. (2018). Pengembangan Pembelajaran Berbasis Blended Learning Pada Mata Pelajaran Etimologi Multimedia. Jurnal Teknlogi Pendidikan, 20(2).

Dwiyogo, W. D. (2018). Developing a Blended Learning-Based Method for Problem-Solving in Capability Learning. TOJET: The Turkish Online Journal of Educational Technology, 17(1), 51-61.

Dziuban, C., Graham, C. R., Moskal, P. D., Norberg, A., \& Sicilia, N. (2018). Blended learning: the 
new normal and emerging technologies. International Journal of Educational Technology in Higher Education, 15(3), 1-16.

Firdaus, Muntaqo, R., \& Trisnowati, E. (2020). Analysis of Student Readiness for Blended Learning Model Implementation in Industrial Era 4.0. Indonesian Journal of Science and Education, 04(01), $48-56$.

Fisher, M., Baird, D. E., Fisher, M., \& Baird, D. E. (2013). Online learning design that fosters student support, self-regulation, and retention. CampusWide Information Systems, 22(2), 88-107.

Galvis, Á. H. (2018). Supporting decision-making processes on blended learning in higher education: literature and good practices review. International Journal of Educational Technology in Higher Education, 15(25), 1-38.

Hanum, F. F. (2019). Implementation Of Educational Technology In Non-Formal Education. Jurnal Ilmiah VISI PGTK PAUD Dan Dikmas, 14(1), 116.

Hawi, F. M., \& Sudira, P. (2019). The Effect of Blended Learning Model to Improve the Conceptual Understanding of Computer and Network Engineering Students The Effect of Blended Learning Model to Improve the Conceptual Understanding of Computer and Network Engineering Students. Journal of Physics: Conference Series, 1413(012023).

Isdisusilo. (2012). Panduan Lengkap Menyusun Silabus dan Rencana Pelaksanaan Pembelajaran. Jakarta: Kata Pena

Isti'anah, A. (2017). The Effect Of Blended Learning To The Students' Achievement In Grammar Class. Indonesian Journal of English Education, 4(1), 16-30.

Jeffrey, L. M., Milne, J., Suddaby, G., \& Higgins, A. (2014). Blended Learning: How Teachers Balance the Blend of Online and Classroom Components. Journal of Information Technology Education: Research, 13, 121-140.

Surat Edaran Nomor 2 Tahun 2020 tentang Pencegahan dan Penanganan COVID 19, (2020).

Kintu, M. J., Zhu, C., \& Kagambe, E. (2017). Blended learning effectiveness: the relationship between student characteristics, design features and outcomes. International Journal of Educational Technology in Higher Education, 14(7).

Lim, D. H., \& Ripley, D. (2007). A Comprehensive Approach for Decision-Making in the Development of E-Learning Instruction in Private Sector Organizations.

Lukitasari, M., Purnamasari, I., Utami, S., \& Sukri, A. (2019). Blended-Problem-Based Learning:
How its impact on students critical thinking skills? Jurnal Pendidikan Biologi Indonesia, 5(3), 425-434.

Murad, D. F., Basukiputra, D. F., Wijaya, M. H., \& Fauzi, M. I. (2019). Sistem Pendukung Media Pembelajaran Menggunakan Chatbot dan LINE Pada PKBM. ULTIMA InfoSys, X(2).

Putu, N., \& Yuliartni, R. (2019). Implementasi Pembelajaran Sosiologi Berbasis Android Pada Program Paket C Di Pkbm Lestari ,. Prosiding SENADIMAS Ke 4, 524-530.

Sadikin, A., \& Hamidah, A. (2020). Pembelajaran Daring di Tengah Wabah Covid-19 ( Online Learning in the Middle of the Covid-19 Pandemic ). Jurnal Ilmiah Pendidikan Biologi, 6(1), 214224.

Sanjaya, G. Y. (2013). Memberikan Fleksibilitas Belajar Mengajar Melalui. Jurnal Pendidikan Kedokteran Indonesia, 2(2), 1-8.

SatgasCOVID. (2020). COVID-19 INDONESIA. November.

Senpai, A. (n.d.). Blended Learning And Cyber Non Formal Education. www.nulisbuku.com

Stone, N. J. (2018). Environmental design, personality, and online learning. Proceedings of the Human Factors and Ergonomics Society, 2, 1171-1175.

Sunarwan, D. (2017). Kemampuan Literasi TIK Tutor Keaksaraan dalam Praktek Kegiatan Pembelajaran di Kelompok. Jurnal Akrab, Aksara Agar Berdaya, V(1), 59-66.

Sutisna, A. (2016). Pengembangan Model Pembelajaran Blended Learning pada Pendidikan Kesetaraan Program Paket $\mathrm{C}$ dalam Meningkatkan Kemandirian Belajar. Jurnal Teknlogi Pendidikan, 18(3), 156-168.

Sutisna, A., Retnowati, E., \& Tijari, A. (2020). Model Pembelajaran Seumur Hidup Berbasis Teknologi Informasi dan Komunikasi untuk Pemberdayaan Perempuan Pedesaan pada PKBM. Jurnal Pendidikan Dan Pemberdayaan Masayarakat (JPPM), 7(1), 46-57.

Youngblood, P., Trede, F., \& Di Corpo, S. (2001). Facilitating online learning: A descriptive study. International Journal of Phytoremediation, 22(2), 264-284.

Yulia, H. (2017). Readiness for Blended Learning viewed from the Students' Attitude towards Learning Aspects. International Journal of Active Learning, 2(1), 15-26.

Zainuddin, Z., \& Keumala, C. M. (2018). Blended Learning Method Within Indonesian Higher Education Institutions. 6(2), 69-77. 